\title{
Skin apolipoprotein $B$ values in normocholesterolaemic patients with coronary artery disease: a discriminatory test?
}

Sir,

An increased plasma lipid concentration is an important risk factor for the development of coronary artery disease ${ }^{1}$ as stressed by Dr Thompson (1984;51:585-8). Recently it has been shown that plasma apolipoprotein concentrations are an even better indicator of risk than plasma lipids ${ }^{12}$ and that cutaneous apolipoprotein $B$ concentrations may also be used as an indicator of risk, particularly in individuals with normal apolipoprotein $B$ concentrations $(<130 \mu \mathrm{g} / \mathrm{dl}) .^{3}$

To determine whether normocholesterolaemic patients with premature coronary atherosclerosis have abnormally high concentrations of skin apolipoprotein B, we studied 40 normocholesterolaemic men aged less than 50 who underwent coronary arteriography for evaluation of chest pain. The upper limits of normal were arbitrarily set at $6 \mathrm{mmol} / 1$ for total plasma cholesterol and at $4.75 \mathrm{mmol} / 1$ for low density lipoprotein cholesterol. None of these patients was on lipid lowering medication. The patients were divided into two groups on the basis of the results of coronary angiography. Group 1 comprised 14 men (aged 43.4(9.24) years (mean (SD)) without important coronary artery stenosis, and group 2 comprised 26 men (aged 46.2(7.2)) with important stenosis of one or more major coronary arteries.

Blood was collected after a 12 hour fast. Lipoprotein subfractions were prepared in a Beckman centrifuge. Plasma cholesterol and triglyceride concentrations and lipoprotein density fractions were measured enzymatically. Plasma concentrations of apolipoproteins A-I and B were measured by electroimmunoassay. Plasma apolipoprotein $\mathrm{E}$ concentration was measured by solid phase radioimmunoassay with monoclonal antibodies as described elsewhere. ${ }^{4}$ Skin biopsy samples (approximately $300 \mathrm{mg}$ ) taken from the inner side of the thigh were homogenised with Polytron PT 10-35 in an ice cold bath. After incubation for one hour at room temperature the homogenate was centrifuged at 5000 $g$ at $10^{\circ} \mathrm{C}$ and skin apolipoprotein B concentration (mean (SD)) was measured by electroimmunoassay. of the supernatant. ${ }^{5}$
Plasma high density lipoprotein cholesterol concentration was significantly $(\mathrm{p}<0.05)$ lower in group $2(0.95(0.02) \mathrm{mmol} / 1$ mean (SD)) than in group 1 $(1 \cdot 17(0.03) \mathrm{mmol} / \mathrm{l})$. There were no other significant differences in plasma lipid variables between groups 1 and 2. Plasma apolipoprotein B, A-I, and E concentrations in groups 1 and 2 were not significantly different. On the other hand, concentrations of cutaneous apolipoprotein $B$ were higher $(p<0.05)$ in patients with coronary heart disease (group 2) $(142.4(9.57)$ than in those without (group 1) $(101 \cdot 6(7 \cdot 69) \mu \mathrm{g} / \mathrm{g}$ fresh tissue).

Linear discriminant analysis was performed to determine to what extent skin apolipoprotein concentrations identified patients with coronary heart disease. In this study cutaneous apolipoprotein B concentration was a better marker for coronary disease than were plasma concentrations of cholesterol, low density lipoprotein cholesterol, and apolipoprotein $B(p<0.05)$.

Among normocholesterolaemic subjects a raised skin apolipoprotein B concentration appears to be the best discriminating factor for identifying those with coronary heart disease. This study suggests the possibility that the risk of coronary heart disease is increased in normocholesterolaemic subjects with normal concentrations of plasma low density lipoprotein cholesterol in whom there is a specific increase in tissue apolipoprotein $\mathbf{B}$.

Philippe Douste-Blazy,

Jean Claude Thiers,

Pierre Valdiguie,

Hubert Bouissou,

Jacques de Graeve,

Pierre Bernadet,

CHU Purpan,

Place du Dr Baylac, 31059 Toulouse Cedex,

France.

\section{References}

1 Whayne TF, Alaupovic P, Curry MD, Lee ET, Anderson $\sim$ PS, Schechter E. plasma apolipoprotein B 
and VLDL, LDL and HDL cholesterol as risk factors in the development of coronary artery dissease in male patients examined by angiography. Atherosclerosis 1981 ; 39: 411-24.

2 Sniderman A, Shapiro S, Marpole D, Skinner B, Teng B, Kwiterovich PO. Association of coronary atherosclerosis with hyperapobetalipoproteinemia [increased protein but normal cholesterol levels in human plasma low density ( $\beta$ ) lipoproteins]. Proc Natl Acad Sci USA 1980; 77: 604-8.
3 De Graeve J, Bouissou H, Thiers JC, Fouet J, Valdiguie $\mathbf{P}$. Is cutaneous apoprotein $\mathbf{B}$ a better discriminator than serum lipoproteins for atherosclerosis? Atherosclerosis 1984; 52: 301-7.

4 Milne RW, Douste-Blazy P, Marcel YL, Retegui L. Characterization of monoclonal antibodies against human apolipoprotein E. F Clin Invest 1981; 68: 111-7.

5 Wulfert E, Legendre C, Thiers JC, De Graeve J, Solera ML, Bouissou H. Determination of apoprotein B in the skin. Pathol Biol (Paris) 1984; 32: 70-2.

\section{Coronary artery bypass grafting and hyperlipidaemia}

Sir,

In a recent editorial (1985; 53: 237-9) Thompson and Sapsford advocate energetic long term treatment of hyperlipidaemia to avert graft failure after coronary bypass surgery. This recommendation is based on recent reports that attempted to link progression of atherosclerosis in the native circulation and in venous bypass grafts to serum lipids. ${ }^{1}$ Other studies from the same institution ${ }^{23}$ and from a different one, ${ }^{4}$ however, found no correlation between serum lipids and progression of coronary atherosclerosis.

In a long term follow up of a series of patients with both internal mammary artery and vein grafts we found graft atherosclerosis exclusively in vein grafts; internal mammary artery grafts in the same patients were spared. ${ }^{5}$ It is clear, therefore, that factors other than lipids play a more important role in graft atherosclerosis. Venous autografts are destined to fail in the long run irrespective of serum lipid concentrations. The treatment of hyperlipidaemia, therefore, is unlikely to have a significant impact on graft survival. The answer probably lies in choosing biologically superior material, such as internal mammary artery grafts.

\section{Ram N Singh, * \\ Julio A Sosa, $\dagger$ \\ *Montefiore Hospital, \\ Pittsburgh, \\ Pennsylvania 15213, \\ USA;}

†Albany Medical Center,

Albany,

New York,

USA.

\section{References}

1 Campeau L, Enjalbert M, Lespérance J, et al. The relation of risk factors to the development of atherosclerosis in saphenous-vein bypass grafts and the progression of disease in the native circulation. A study 10 years after aortocoronary bypass surgery. $N$ Engl $\mathcal{F}$
Med 1984; 311: 1329-32.

2 Moise A, Théroux P, Taeymans Y, et al. Clinical and angiographic factors associated with progression of coronary artery disease. $\mathcal{F}$ Am Coll Cardiol 1984; 3: 659-67.

3 Moise A, Bourassa MG, Théroux P, et al. Prognostic significance of progression of coronary artery disease. Am $\mathcal{F}$ Cardiol 1985; 55: 941-6.

4 Kramer JR, Matsuda Y, Mulligan JC, Aronow M, Proudfit WL. Progression of coronary atherosclerosis. Circulation 1981; 63: 519-26.

5 Singh RN, Sosa JA, Green GE. Internal mammary artery versus saphenous vein graft. Comparative performance in patients with combined revascularisation. Br Heart $\mathcal{F}$ 1983; 50: 48-58.

This letter was shown to the authors, who reply as follows:

Sir,

The contention of Singh and Sosa that internal mammary artery grafts develop less in the way of late atheromatous changes than do saphenous vein grafts has no bearing on whether the latter survive longer in normolipidaemic than in hyperlipidaemic subjects. This is a separate issue. Whether or not internal mammary artery grafts last longer may be relevant to patients who will need coronary artery bypasses in the future but not to the many thousands who already have saphenous vein grafts. We believe that the study of Campeau et al ${ }^{1}$ showed a definite correlation between hyperlipidaemia and late vein graft closure and we consider that this justifies lipid lowering treatment, although we acknowledge that this advice is based on data showing nonprogression of disease in native vessels ${ }^{23}$ rather than in vein grafts.

G R Thompson,

R Sapsford,

Medical Research Council Lipoprotein Team, and

Department of Surgery, Royal Postgraduate Medical School,

Hammersmith Hospital,

Ducane Road, London W12 0HS. 